Todos se han ido

poco a poco

uno por uno

en silencio

también mi calle se va

con todas sus casas

y sus jardines

y los ladridos de sus perros

Ya no escucho

la voz de mi abuela en mi oído

no siento la dulce caricia

de sus arrugas

en mi rostro

Ya no queda nada

Sólo tengo frente a mí

en este otoño frío

el inquietante ojo de la aguja

\title{
EL LOCO GENOVÉS
}

Para Julián Meza

El barco zarpó

rumbo a Las Indias

-eso dijiste-,

pero no estabas seguro. 
En realidad,

nunca estuviste seguro de nada:

ni del amor de tu mujer, ni del origen de tus hijos, tampoco de tu entusiasmo, mucho menos de ti mismo.

Caminabas solo por las plazas y bebías vino y fornicabas borracho con las hetairas de turno.

Te llamaban el genovés loco y lo aceptabas.

Tal vez por eso te impusiste el viaje, quizá para escapar a tu locura o para acendrarla; para huir de tu mujer y de tus hijos; para huir, sobre todo, de ti mismo.

Los vientos eran propicios cuando zarpaste, también los augurios.

La tripulación bebió contigo un vino dulce y conciliatorio, 
comieron arenques

y sardinas,

y por las noches cantaban

esas canciones tristes

que te recordaban un amor

que nada tenía que ver

con el amor de tu mujer

ni el de tus hijos.

$\mathrm{Al}$ amanecer,

después de varios meses de travesía,

comprendiste que ese viaje

no tendría fin,

que del otro lado del mar

no había nada,

que todo había sido,

-sencillamente-

un sueño,

el sueño alucinado y terco

de un loco genovés.

Y cerraste los ojos.

Nunca te atreviste

a revelarle a la tripulación

lo que habías divisado

a lo lejos,

en el horizonte,

en aquel amanecer insólito:

Detrás del encrespado oleaje, en ese juego de luces 
que estallaba

entre el amarillo y el malva,

no había nada,

absolutamente nada,

sólo esa sonrisa amable,

al borde del océano,

que anunciaba el abismo.

\section{TIRESIAS}

Eras ciego, pero lo conocías todo.

Sabías del frío y de la lluvia, del trigo y del sol y del viento y de las hojas que caen en otoño.

Sabías todo del amor, tú, que nunca amaste a una mujer; tampoco a un hombre.

Eras ciego

y desgarbado y flácido, pero en ti habitaban el hombre y la mujer y todas sus caricias.

No necesitabas nada ni a nadie, te bastabas a ti mismo y predecías el destino de los hombres.

¿Cómo te llegó la muerte?

Por cansancio, dices, 